\title{
Review
}

\section{Capitalism: A conversation in critical theory}

\author{
Nancy Fraser and Rahel Jaeggi \\ Cambridge, Polity, 2018 iii + 244pp., \\ ISBN 9789745671574
}

Contemporary Political Theory (2020) 19, S153-S156. https://doi.org/10.1057/s41296018-00304-w; published online 1 January 2019

This book aims to bring the study of capitalism back to the forefront of critical theory. In doing so, Nancy Fraser and Rahel Jaeggi lay out a bold agenda for a theoretical approach that, in their view, has become almost indistinguishable from liberalism (pp. 5-6). There are three main aspects of earlier iterations of critical theory that the authors reprise in this work. First, both thinkers engage in unabashed grand theorizing of capitalist society, whether the latter is understood as an 'institutionalized social order' (Fraser) or as a 'form of life' (Jaeggi). The picture of capitalism that emerges eschews its reduction to a purely economic system, and instead encompasses its social, political, and natural background conditions and entanglements. Second, as Benhabib (2018) has recently argued, a critical theory of society that builds on the legacy of the Frankfurt School needs to focus on crisis. Fraser and Jaeggi offer just such an analysis, beginning from the observation of a 'pervasive sense that we are caught in the throes of a very deep crisis - a severe systemic crisis' (p. 2), but also analyzing the more 'objective' crisis tendencies and contradictions of capitalism. Finally, deploying a phrase from Marx that is repeated throughout the book, the authors argue that critical theory aims to provide 'self-clarification of the struggles and wishes of the age' (p. 11). In light of the 'widespread agreement that capitalism is (again) a problem' (p. 2), and of the rise of right- and left-wing populist movements and parties around the world which signals the crumbling of neoliberalism's legitimacy (p. 222), critical theory at its best can help social actors develop a clearer understanding of the conjuncture, including its latent emancipatory possibilities. To describe such a project as ambitious would be an understatement, but Fraser and Jaeggi's execution displays the clarity, insight, and rigor that one would expect from two thinkers at the peak of their abilities.

While talk of crisis has become ubiquitous - financial and sovereign debt crises, ecological crisis, the crisis of care, the crisis of democracy - Fraser's ambition is to 'disclose the structural grounds of multiple crisis tendencies in one and the same social totality: capitalist society' (p. 10). The first two chapters showcase her

(C) 2019 Springer Nature Limited. 1470-8914 Contemporary Political Theory Vol. 19, S2, S153-S156 
inimitable capacity for synthesizing diverse literatures - Marxism, feminism, ecology, and postcolonialism - into an elegant conceptual framework. Central to Fraser's account is her claim that the capitalist economy relies upon several noncommoditized background conditions: unwaged social reproductive labor, nonhuman nature, public powers, as well as the confiscated labor and resources of racialized groups. Not only does the capitalist economy depend on these activities and resources, it also disavows their value. Treating social reproduction, public power and nature as 'free gifts,' capitalists 'don't concern themselves with replenishing them' (p. 154). Capitalism is thus inherently crisis prone because the capitalist economy's relentless drive for accumulation results in the destabilization of its own non-economic background conditions. Fraser argues that systemic crises and social struggles over where the boundaries between the various spheres of activity in capitalist society are drawn find resolution in new relationships between the capitalist economy and its background conditions, which in turn constitute different historical regimes of accumulation: mercantile capitalism, competitive liberal capitalism, state-managed monopoly capitalism, and the current era of globalizing financialized capitalism. While the narrative is compelling, it is painted in very broad strokes, which might frustrate more historically inclined readers.

In chapter three, the authors turn their attention to the question of 'what is wrong with capitalism'? (p. 115) While each offers her own answers to that question, the balance tilts more in favor of an exposition of Jaeggi's thought, which is especially welcome given that many readers will be less familiar with her work, some of which has only very recently been translated into English. The chapter begins with a useful analysis of three main strategies of criticizing capitalism: functionalist, moral ethical (p. 116). While each has its strengths and limitations, Jaeggi suggests that the 'weaknesses can be overcome by putting all the "dimensions" together' ( $\mathrm{p}$. 137). The result is her approach to understanding capitalism as a form of life, namely a social formation in which economic and social practices stand on a single continuum that is 'constituted by normative criteria of appropriateness' (p. 137). As such, she hopes to avoid the lack of normativity within purely functionalist critiques; the problem that much normative critique is too removed from the actual contradictions and values of a given social order; and finally the difficulty of establishing 'well-grounded ethical standards' (p. 128). A critique of capitalism as a form of life would then disclose its irrationality and injustice by highlighting the dysfunctions created by its own deep contradictions, and the fact that it 'blocks social experiences and learning processes' and is thus 'a distorted way to react to crises' (p. 138). One frustration I had with this discussion is that Jaeggi seems to offer more of a protocol for critique than a critique itself, something she admits when she describes it as 'formalistic' at the end of the chapter (p. 164). Admittedly, the chapter does offer some more concrete critical claims: capitalism limits autonomy by restricting decisions about how to use the socially produced surplus to the private owners of capital (p. 131); it prevents us from fully appropriating, taking 
responsibility for and carrying forward our 'common history' (p. 133); and it is alienating, in the sense that it distorts the 'appropriation of our own wishes and deeds' (p. 135). Further work in this vein might fruitfully develop a more targeted critique of the contemporary form of capitalism, as opposed to capitalism tout court.

These conceptual analyses culminate in the fourth chapter, 'Contesting Capitalism.' Here Fraser brings together her earlier work on redistribution and recognition, as well as her addition of the 'missing third' (emancipation) to Karl Polanyi's account of the double-movement between marketization and social protection (p. 191). Based on this framework, Fraser conceptualizes progressive neoliberalism, exemplified by Hillary Clinton but stretching back to the presidency of Bill Clinton, as involving the 'veneer of emancipation' and recognition spread onto regressive policies of marketization and the dismantlement of social protection (p. 201). While this strategy worked for New Labour in the UK and the US Democrats for a time, it sacrificed members of the 'declining industrial centers' ( $p$. 203), many of whom were then captivated by populist economic rhetoric. As an alternative to forms of populism that are reactionary on the recognition front, Fraser proposes what she calls progressive populism, which she associates with the candidacy of Bernie Sanders (among others). In conceptual terms, this would combine 'an egalitarian, pro-working-class distributive program with an inclusive, nonhierarchical vision of a just recognition order - or ... emancipation plus social protection' (p. 213). The political coalition capable of adopting such a program must unite the traditional industrial working class with those who "perform domestic, agricultural, and service labor - paid and unpaid, in private firms and private homes, in the public sector and civil society - activities in which women, immigrants, and people of color are heavily represented' (p. 217). In effect, progressive populism must woo voters away from progressive neoliberalism on the one hand, and the hyper-reactionary-neoliberalism of Trump on the other (p. 220). In this context, the political significance of an expanded conception of capitalism comes into clearer focus. If 'struggles against racism, imperialism, and sexism respond to forms of domination that are every bit as real, unjust, and deeply anchored in capitalist society as those that give rise to class struggles' (p. 166), then it is at least conceivable that 'aspirations for emancipation and for social protection' - LGBTQ rights and the plight of the white working class for example 'which are currently posed as mutually antithetical, can in fact be rendered compatible and mutually supporting' (p. 207). How exactly to go about doing so, however, remains unclear.

The scope of the project undertaken in this book inevitably leaves questions unanswered, although its conversational format and the fact that Fraser and Jaeggi do not agree on every detail means that a number of objections are raised and answered. However, in a book so centered on crisis, I was somewhat surprised to find no mention of the ongoing border/refugee/migrant 'crisis.' Perhaps this is

(C) 2019 Springer Nature Limited. 1470-8914 Contemporary Political Theory Vol. 19, S2, S153-S156 S155 
because this particular situation fails to meet the objective criteria of a crisis that the authors adopt (p. 163), and it is worth noting that they do consider the causes of the fear of immigrants. Still, even if the 'crisis' is more fabricated than genuine, it still raises the question of the position that progressive populism should take regarding matters of international concern, including borders, migration, and global poverty. Given the challenges of convincing declining working class communities 'that the forces promoting militarism, xenophobia, and ethnonationalism cannot and will not provide them with the essential material prerequisites for good lives' (p. 220), to what extent would it be acceptable for progressive populism in the global North to prioritize - as a matter of strategy rather than principle 'emancipation plus social protection' for its own citizens and residents? No doubt other readers will raise different questions. Far from signaling a weakness of the book, however, I believe that this confirms its success at laying out an agenda for the renewal of critical theory that subsequent works can carry forward.

\section{Reference}

Benhabib, S. (2018) Below the Asphalt Lies the Beach: Reflections on the Legacy of the Frankfurt School. Boston Review, October 9, 2018. Accessed December 8, 2018, from http://bostonreview.net/ philosophy-religion/seyla-benhabib-below-asphalt-lies-beach.

Publisher's Note Springer Nature remains neutral with regard to jurisdictional claims in published maps and institutional affiliations.

James A. Chamberlain Mississippi State University, Starkville, MS 39759, USA jac1287@msstate.edu 